\title{
A Literature Waiting in the Wings for History: A Tribute to Patrick Chabal
}

\author{
Margarida Calafate Ribeiro
}

Centro de Estudos Sociais, Universidade de Coimbra

I would like to begin by making clear that I am an interloper on the terrain of Portuguese-language African literatures. Over my career, their varied manifestations have drawn me in, repeatedly revealing themselves to be key to my understanding of contemporary Portugal and its relationship with its former empire. I would like to register my profound gratitude to Patrick Chabal in particular, along with other colleagues and writers, who have shown me other means of expression, other archives and other ways of understanding those who centuries ago were startled by the unexpected arrival of a boat full of Europeans in the middle of the Indian Ocean. Indeed, Luís de Camões captured the curiosity in their bewilderment, as he had them question in their native tongues the Portuguese explorers:

$$
\begin{aligned}
& \text { As they ate contentedly, they began } \\
& \text { Questioning in the Arab language, } \\
& \text { - 'Where are you from? What do you } \\
& \text { Want? What oceans have you crossed?' }
\end{aligned}
$$

Regardless of who discovered whom, an issue this passage undoubtedly raises, I am more interested in highlighting the fact that the questions the natives posed, in an apparently naive way, are central to the identity of the people Portugal's adventurers came across. From the moment of first contact, one of the longest and most asymmetrical dialogues in memory was begun.

That asymmetry has always troubled me. Where are the texts from this long, tense and essentially deaf dialogue? Where are the texts that interrogate the European condition? Where are the texts that describe territories beyond a European gaze? Where are the texts written in languages beyond Portuguese?

In the margins of an apparently hegemonic Eurocentric discourse, there were always signs that bore witness to the existence of other ethno-cultural subjects. The conditions of their enunciation were plunged into silence during colonialism, as Spivak points out in her seminal article 'Can the subaltern speak?' (1988). Today, historians, literary critics and scholars must rescue those other discourses from the margins of colonial rhetoric where other histories do

1 Luis Vaz de Camões, The Lusíads, translation, introduction and notes by Landeg White (Oxford and New York: Oxford University Press, 1997), from Canto I, Stanza 50 (p. 13).

Portuguese Studies vol. 30 no. 2 (2014), 00o-0oo

(C) Modern Humanities Research Association 2014 
exist. These histories underpin the first texts in Portuguese in the literatures of São Tomé, Guinea-Bissau, Angola, Mozambique and Cape Verde. They are texts that inscribe a cultural difference that would eventually mature into a demand for independence. That is why literary scholars, in particular of Portugueselanguage African culture, reflect in their studies on the intrinsic relationship between politics and literature. Field-founders like Manuel Ferreira, Alfredo Margarido, Maria Aparecida Santilli, Michel Laban, Russell Hamilton, Gerald Moser, Irene Guerra Marques, Laura Padilha, Benjamim Abdala Júnior, and José Luandino Vieira, as well as the generation that followed them, including Pires Laranjeira, Rita Chaves, Fátima Mendonça, Tânia Macedo, Moema Parente Augel, David Brookshaw, Patrick Chabal, Inocência Mata, Ana Mafalda Leite, Francisco Noa, Gilberto Matusse, Odete Costa Semedo, Phillip Rothwell, Hilary Owen among so many others, understood the key role of literature in an understanding of history, from the moment the Portuguese arrived in Africa, throughout their long colonial presence, and the struggles for independence. Even today, the relationship remains strong.

Among the many people who taught me to look at those literatures, Patrick Chabal occupies pride of place. I had the privilege of working with him as a doctoral student and then as a colleague. Like me, Patrick was not a specialist in the literatures of Portuguese-language Africa. He wasn't even a literary scholar. Rather, he was a historian and political scientist who quickly understood the importance of these literatures for his work. He understood them as profoundly linked to political processes. He saw them as a literature inherently linked to history, in fact, a literature waiting in the wings for history, as we can see in the themes he developed in his introduction to The Postcolonial Literature of Lusophone Africa. We need only remember José Luandino Vieira's literary project to understand how the language of colonization and oppression (as indeed Portuguese was) can be transformed into the language of liberation. We need only remember the Angolan, Pepetela's literary project to understand literature as the recreation of a historiographical imagination, from its precolonial foundational myths in Lueji, through the Dutch occupation resisted by Angolans and Portuguese in A Gloriosa Família, and the modern colonial era and its end in Yaka, right up to the present day in Predadores. Likewise, we just have to remember a book like Manuel Rui's A Casa do Rio or João Paulo Borges Coelho's A Crónica da Rua 513.5 to feel completely decolonization's fracturing of the historical process and of the subjectivities of those who played a leading role in it. Here is where history and literature join forces, not just as mutual sources, but through the possibilities literature offers for representing those moments in individual histories that fuse with the collective history of a people. Those moments produce subjectivities, feelings, emotions - none of which history can capture, or give. That was the essential aspect Patrick Chabal understood from his own discipline, looking out on literatures that were so viscerally connected to politics and history. That is why in 1996, when 
he launched The Postcolonial Literature of Lusophone Africa, he wrote in his introduction about the importance of language and metropolitan culture in the development of these literatures. He rejected simplistic and dated views, formed on the coat-tails of a legitimate political rejection of colonialism. He understood that rejection should not include a complete denial of the former metropolis's culture as a decisive influence that actually enabled the development of postcolonial literatures. For Patrick Chabal, the denial of a dual legacy - both Western and African - is both analytically sterile and politically weak. The importance of Patrick Chabal's pioneering work is its link to fundamental issues about the elaboration of the histories of literature, handbooks or readers, and consequently to the canons these form. Understanding the inclusion and exclusion of writers, at the heart of the conception of histories of literature, anthologies and collections of texts, was crucial to him. Patrick Chabal shows the permeability of literature as a genre, and its power to include as foundational texts, historiographical sources, which are themselves unique moments in literature. We just need to remember the inception of Brazilian literature with the Letter by Pêro Vaz de Caminha as proof. He also raised the question of cultural and literary temporality linked to the political and cultural identity of a country. Finally, he raised the question of determining from which space literature speaks - what the place of its enunciation is. In essence, the question Patrick Chabal pioneers is the paradox of literary nationalisms, characterized by including and excluding authors, mixing political and economic reasons with historical, literary and aesthetic ones. As these nationalisms do this, they risk eliminating something that constitutes their very identity: the long colonial presence. In this, Patrick Chabal echoes other scholars and writers, who point to what José Luandino Vieira would come to call the 'black holes' of Angolan literature, things as simple as deciding where to place colonial literature, and writers working prior to what became Angola. Deciding where to place writers in the diaspora. To ask ourselves what, at the end of the day, Angolan or Mozambican literature is, how to teach it, and how to interpret it.

That is why the post-independence generation of literary critics has concentrated not just on narrating the histories of these literatures, following the traditional European model of periodization, but rather on identifying the literary object of these new nations and thus contributing to the construction of a possible canon by identifying what Antonio Candido, in reference to Brazilian literature, termed a 'literary system'. Patrick Chabal's cornerstone contribution in The Postcolonial Literature of Lusophone Africa, beyond spreading its study in the English-speaking world and thus enabling more comparative studies of the African continent, is his sensitivity to literature as a space to understand subjectivities inherent to historical processes. Liberation thus becomes entwined with the nation's language and with the need to create an alternative narrative to that of the colonizer.

As he asserts, in the modern era, the most visible expression of narratives 
opposed to the colonizer's was the grand narrative engendered by the anticolonial struggle. It focused on a denunciation of colonialism and its vices and on the elaboration of a future national project. Through this narrative, more focused on hope for the future than a revision of the past, more Eurocentric than nationalist and indigenous, the idea of Angola for the Angolans and Mozambique for the Mozambicans was born. This would come to be known as Angolanness, Mozambicanness, Cape Verdeanness, etc. As Patrick Chabal points out, the appeal to post-independence equality, taken to extremes by the single party, caused the dramatic erasure of differences that formed the social and cultural fabric of the recently freed countries. It was contradictory. Often, it was synonymous with a continuation of the imperial mechanisms whose influence continued to be felt, even if it was not initially so obvious in the euphoria of the revolutionary moment, whipped up by literature. In fact, combat literature was an armed wing, encouraging the struggle for the nation-to-be by inventing a single past, from which Guineans, Mozambicans and Angolans could emerge and move forward united without any cracks or differences, against a common enemy: colonization and its legacies. Portuguese was the language of symbolic representation for what were conceived as nation-states as drafted by their first leaders. This decision guaranteed a cultural identity particularly in Angola and Mozambique in their southern African context, by reducing their linguistic complexity to a State expressed only in Portuguese. At the same time, it relegated to the background the languages of many different peoples. Patrick Chabal, over his career, raised the questions: how do we situate the idea of the nation, brought into being through an anticolonial struggle, in relation to other grand narratives such as race, religion, ethnicity and gender? What is their place vis-à-vis the 'new' discursive hegemony of the national project?

These questions, raised by a historian of Africa whose language was not Portuguese, were fundamental for our critical gaze on these literatures, and once again it was to literature that Patrick Chabal went in search for answers. It was through literary expression in Portuguese, in theatre, sculpture and painting, that other perspectives emerged. At the same time as it nurtured and strengthened the national project, it also opened up alternatives to the political hegemony. In sum, literature began rejecting, amending or questioning the hegemony of the national project, interrogating its value as representative of a nation that simultaneously ruptures from the state. That is why some writers and artists tried in their work to make sense of the violence and destruction inflicted on their countries, assailed by the immensity of multiple wars. That is the only way to understand the hatred and repulsion expressed in José Craveirinha's Babalaze das Hienas, or Rui Knopfli's tragic poetic feeling, or José Luandino Vieira's literary silence, or Odete Semedo's unanswered questions. Quietly, a younger generation developed their own literary projects, including Mia Couto, Ungulani Ba Ka Khosa, Luís Carlos Patraquim, Lilia Momplé, Eduardo White, 
João Paulo Borges Coelho, Paulina Chiziane, Ana Paula Tavares, João de Melo, João Maimona, José Luis Mendonça, Abdulai Sila, Tony Tcheka, Conceição Lima among many others. They challenged from different perspectives and in various hues the macro-narrative of a single voice. They offered multiple voices that belied the fallacy of rigid, geographical and cultural boundaries with which many insisted on wrapping up the literary imagination of the nation. Patrick Chabal, with Ana Mafalda Leite, David Brookshaw, Moema Parente Augel and Caroline Shaw, brought these texts to the English-speaking world, in a work that today is a key reference worldwide because of the many questions it raises. It is a heritage of reflection for all scholars of Portuguese-language African literatures, literatures duly individuated in the volume.

In this vein of deploying a multidisciplinary and political approach in the analysis of Portuguese-language African literatures, I organized at Coimbra's Social Studies Centre, where I work, courses on each of these nations' literatures. These led to several books to which professors of literature, historians, political scientists, colleagues from law, anthropology and sociology contributed: Lendo Angola (2008), Moçambique: das palavras escritas (2008), Literaturas da GuinéBissau: cantando os escritos da história (2011), Literaturas Insulares: leituras e escritas de Cabo Verde e S. Tomé e Príncipe (2011). Together, both speakers and non-speakers of Portuguese entered into dialogue with themes and terrain that Patrick Chabal's work had first ploughed. 